Dunamis: Jurnal Teologi dan Pendidikan Kristiani

Volume 6, Nomor 1 (Oktober 2021)

ISSN 2541-3937 (print), 2541-3945 (online)

https://www.sttintheos.ac.id/e-journal/index.php/dunamis

DOI: 10.30648/dun.v6i1.500

Submitted: 14 Januari 2021

Accepted: 5 Mei 2021

Published: 30 Oktober 2021

\title{
Maksud Yesus Dalam Peristiwa Baptisan: Sebuah Tanggapan Teologis Terhadap Marcus J. Borg
}

\author{
Yudi Jatmiko \\ Gereja Presbyterian Bukit Batok, Singapura \\ yudijm@gmail.com
}

\begin{abstract}
Jesus' baptism does not only refer to His divine role, but moreover to His divine identity. This is a theological declaration that He is God. However, Marcus J. Borg asserted that Jesus' baptism was Jesus' deep spiritual awareness toward spiritual world and the presence of God's Spirit in His life. This does not indicate His divinity at all. Based on these two contradictory views, a problem remains to be solved: Is Borg's assumption correct? What is actually Jesus' true intention in His baptism? This was the focus of the research. This writing exerted to describe particularly Borg's view on Jesus' baptism, analyzed and responded to his view according to evangelical perspective. Despite the fact that Borg's view on Jesus' baptism has widely garnered support from modern theological readers, his theology is still far from orthodox theology because it was too socio-anthropological based analysis and ignored the Bible as God's revelation.
\end{abstract}

Keywords: Jesus' baptism; Marcus J. Borg; the metaphorical language of the Gospel; Jesus' spiritual awareness; Historical Jesus; Christ of Faith

\begin{abstract}
Abstrak
Baptisan Tuhan Yesus bukan hanya merujuk kepada fungsi jabatan-Nya, tapi lebih daripada itu, yaitu kepada identitas ilahi-Nya. Ini merupakan sebuah deklarasi teologis bahwa Ia adalah Allah. Tetapi Marcus J. Borg menyatakan bahwa baptisan Yesus sebagai sebuah kesadaran spiritual Yesus yang mendalam akan dunia roh dan kehadiran Roh Allah dalam hidup-Nya. Hal ini sama sekali tidak mengindikasikan keilahian-Nya. Mengaitkan kedua pandangan yang bertolakbelakang ini, muncul permasalahan: benarkah asumsi Borg di atas? Apakah sebenarnya yang menjadi intensi Yesus dalam peristiwa baptisan tersebut? Inilah yang menjadi fokus penelitian penulis. Tulisan ini berusaha untuk memaparkan secara khusus pandangan Borg dalam peristiwa baptisan Yesus dan menganalisis serta menanggapi pandangannya menurut perspektif injili. Terlepas dari pandangan Borg yang digemari di kalangan pembaca teologi modern tentang baptisan Yesus, pemikirannya masih jauh dari teologi ortodoks oleh karena terlalu berpijak pada analisis secara sosio-antropologis dan mengabaikan Alkitab sebagai wahyu dari Allah.
\end{abstract}

Kata Kunci: baptisan Yesus; Marcus J. Borg; metafora bahasa Injil; kesadaran spiritual Yesus; Yesus Sejarah; Kristus Iman 


\section{PENDAHULUAN}

Peristiwa baptisan Tuhan Yesus oleh Yohanes Pembaptis sebagaimana disaksikan oleh keempat Injil adalah peristiwa yang signifikan (Mat. 3:13-17; Mrk. 1:9-11; Luk. 3:21-22; Yoh. 1:32-34). Signifikansi ini terletak bukan sekadar pada nilai historis yang ada, ${ }^{1}$ tetapi juga pada makna teologis yang terkandung di balik peristiwa tersebut. ${ }^{2}$ Baptisan Tuhan Yesus bukan hanya merujuk kepada fungsi jabatan-Nya, tapi lebih daripada itu, yaitu kepada identitas ilahi-Nya. James R. Edwards merumuskan hal ini dengan tepat ketika ia mengatakan bahwa "the baptism is the keystone in the life and ministry of Jesus. The empowerment by the spirit to be God's Servant, and the declaration from heaven, 'You are my Son,' enable Jesus not only to speak and act for God but as God."3 Baptisan Tuhan Yesus adalah sebuah deklarasi teologis bahwa Ia adalah Allah.

Jauh dari konsepsi sebagaimana diuraikan di atas, Marcus J. Borg, seorang

\footnotetext{
${ }^{1}$ Aspek historisitas baptisan Yesus umumnya tidak terlalu dipermasalahkan oleh para teolog Yesus Sejarah (Robert L. Webb, "Jesus' Baptism: Its Historicity and Implications," Bulletin for Biblical Research 10, no. 2 (2000): 261-309, accessed October 2, 2021, https://www.jstor.org/stable/ 26422221.).

${ }^{2}$ Yang seringkali menjadi perdebatan ialah mengenai aspek kristologis dari peristiwa baptisan tersebut (lih. Charles G. Dennison, "How Is Jesus the Son of God? Luke's Baptism Narrative and Christology," Calvin Theological Journal 17, no. 1 (1982): 6-25.).

3 The Gospel According to Mark (Grand Rapids: Eerdmans, 2002), 38.

4 Marcus J. Borg, Jesus: Uncovering the Life, Teachings, and Relevance of A Religious
}

penggiat Jesus Seminar menyatakan bahwa baptisan Yesus memang bersifat historis, namun menurutnya baptisan yang membuktikan identitas ilahi-Nya adalah sebuah kesimpulan teologis yang bersifat "postEaster."4 Jesus Seminar ialah sebuah kelompok yang didirikan oleh Robert Funk dan berjumlah kurang lebih 70 orang sarjana kritis dari kalangan teologi, sekular, dan sutradara film. Bersama-sama mereka memutuskan bagian-bagian Alkitab mana yang sungguh-sungguh merupakan perkataan Yesus dan yang bukan. ${ }^{5}$ Borg menyarankan untuk melihat peristiwa baptisan Yesus paling jauh ialah dari perspektif spiritual, karena menurutnya, "Jesus . . . is spiritual in that his relationship to the spirit of God was the central reality in his life, the source of all that he was. We cannot glimpse the historical Jesus unless we take with utmost seriousness his relationship to the world of Spirit."6 Maksudnya ialah bahwa sematamata sebagai seorang manusia Yahudi, Yesus memiliki kesadaran yang mendalam

Revolutionary (New York: HarperSanFransisco, 2006), 121. Maksudnya ialah sebuah kesimpulan yang lebih merupakan hasil formulasi doktrinal alihalih data historis.

5 Daniel Lucas Lukito, "490 Tahun Reformasi : Apakah Sola Scriptura Masih Secara Konsisten Menjadi Pegangan Gereja-Gereja Reformed Masa Kini?," Veritas: Jurnal Teologi dan Pelayanan 8, no. 2 (2007): 151-168, accessed October 2, 2021, http://repository.seabs.ac.id/handle/123456789/158. ; Marcus J. Borg, "What Did Jesus Really Say?," Bible Review 5, no. 5 (1989): 18-19.

6 Marcus J. Borg, Jesus: A New Vision (San Francisco: Harper\&Row, 1987), ii. 
akan dunia roh dan kehadiran Roh Allah dalam hidup-Nya. Ia berpendapat bahwa kesadaran inilah yang mewarnai tiap segi kehidupan Yesus. ${ }^{7}$ Mengaitkan kedua pandangan yang bertolakbelakang ini, muncul permasalahan: benarkah asumsi Borg di atas? Apakah sebenarnya yang menjadi intensi Yesus dalam peristiwa baptisan tersebut? Inilah yang menjadi fokus penelitian penulis. Terlepas dari pandangan Borg yang digemari dikalangan pembaca teologi modern tentang baptisan Yesus, berdasarkan penelitian mendalam terkait konsep metafora bahasa Injil, konsep kesadaran spiritual Yesus, dan konsep pemisahan antara Yesus pre-Easter (prapaskah) dan post-Easter (pascapaskah), penulis meyakini bahwa konsepsi Borg masih jauh dari teologi yang ortodoks.

\section{METODE PENELITIAN}

Tulisan ini berusaha untuk pertama, memaparkan secara khusus pandangan Borg dalam peristiwa baptisan Yesus. Pada bagian ini juga akan diuraikan argumentasiargumentasi yang mendasari pemikirannya serta metodologi yang digunakan; dan kedua, menganalisis dan menanggapi pandangan Borg menurut perspektif injili. Yang penulis maksud dengan perspektif injili dalam bagian ini ialah perspektif yang diba- ngun di atas dasar kebenaran Alkitab, PL dan PB, sebagai otoritas tertinggi yang inerrant dan berwibawa terhadap konsep teologis maupun kehidupan praktis seorang peneliti teologi. ${ }^{8}$ Pada bagian ini juga akan diuraikan tentang maksud Yesus dalam peristiwa baptisan menurut perspektif injili.

Fokus penelitian ini dipilih dengan mempertimbangkan beberapa hal: pertama, peristiwa baptisan Tuhan Yesus adalah topik yang erat kaitannya dengan studi Yesus Sejarah dan Kristus Iman; kedua, pemaknaan dari intensi Yesus terhadap peristiwa tersebut akan sangat mempengaruhi konsep teologis mengenai pribadi dan karya-Nya. Oleh karenanya, studi yang mendalam mengenai hal ini amat signifikan. Dalam tulisan ini, penulis memilih untuk meneliti hanya pandangan Borg dengan mempertimbangkan dua alasan: pertama, Borg adalah tokoh yang paling vokal, berpengaruh dan banyak mengaitkan serta menulis tentang hubungan baptisan Yesus dengan konsep Yesus spiritual; kedua, penulis berharap mendapatkan penelitian yang lebih mendalam dan terfokus pada topik ini sehingga memberikan kontribusi yang baik bagi studi Yesus Sejarah.

${ }^{8}$ R. V. Perard, "Evangelicalism," in Evangelical Dictionary of Theology, ed. Walter A. Elwell (Grand Rapids: Baker, 1982), 379-382. 


\section{HASIL DAN PEMBAHASAN}

\section{Makna Baptisan Yesus Menurut Perspektif Marcus J. Borg}

Menurut Borg, baptisan Yesus tidak boleh dimaknai dalam perspektif kristologis. Ia berargumen bahwa hal ini disebabkan paling tidak oleh tiga hal, yaitu konsep metafora bahasa Injil, konsep kesadaran spiritual Yesus, dan konsep pemisahan antara Yesus pre-Easter (prapaskah) dan postEaster (pascapaskah). ${ }^{9}$

\section{Konsep Metafora Bahasa Injil}

Dalam konsepsi teologis Borg, membaca Injil hanya melalui perpektif historis-literal adalah sebuah jenis pembacaan yang naif dan tidak kritis. ${ }^{10}$ Pembacaan yang demikian mengabaikan fakta bahwa Injil adalah semata-mata produk tulisan manusia ${ }^{11}$ dan telah mengalami perkemba-

\footnotetext{
9Istilah "pre-Easter" dan "post-Easter" adalah istilah teknis yang Borg gunakan dalam berbagai tulisannya mengenai identitas Yesus (misalnya dalam Marcus J. Borg, The God We Never Knew: Beyond Dogmatic Religion to A More Authentic Contemporary Faith (New York: HarperCollins, 1997), 84-104.). Bahkan Borg sendiri mengatakan bahwa "I would like to suggest a terminological shift that could affect our thinking and conversation about this subject. Namely, to use the terms familiar from the preceding chapter, I would like to replace the phrases "the Jesus of history" and "the Christ of faith" with "the pre-Easter Jesus" and "the postEaster Jesus" (Marcus J. Borg, Jesus in Contemporary Scholarship (Valley Forge: Trinity, 1994), 195.). Namun karena faktor penerjemahan dan keseragaman, penulis akan menggunakan istilah "prapaskah" (untuk merujuk pre-Easter) dan "pascapaskah" (untuk merujuk post-Easter) dalam keseluruhan tulisan ini.

${ }^{10}$ Marcus J. Borg, Meeting Jesus Again for the First Time: The Historical Jesus \& the Heart of
}

ngan begitu rupa dalam tradisi lisan. ${ }^{12}$ Ia mengutarakan maksudnya mengenai hal ini demikian:

The gospels are not a direct divine product, as notions of biblical inerrancy suppose. Rather as documents written within early Christian communities, they are human products. They tell us how our spiritual ancestors in these communities saw Jesus and his significance. ${ }^{13}$

Sebagai sebuah hasil karya manusia, Borg melihat Injil bukanlah kumpulan tulisan yang diinspirasikan oleh Allah, melainkan merupakan hasil refleksi para penulis mengenai Allah. Alih-alih sebuah dokumen historis yang obyektif, Injil harus dimaknai sebagai proyeksi spiritual yang subyektif. ${ }^{14}$ Selain itu, sebagai sebuah produk yang berkembang, Injil telah kehilangan bentuk aslinya yang merujuk kepada perkataan dan perbuatan Yesus yang otentik. ${ }^{15}$ Aspek per-

Contemporary Faith (New York: HarperCollins, 1994), 3-6., sebagaimana dikutip oleh Nicole Christine Frazer, "Marcus Borg: A New Vision of Jesus," Global Journal of Classic Theology 3, no. 2013 (10AD): 1-18.

${ }^{11}$ Borg, Jesus: Uncovering the Life, Teachings, and Relevance of A Religious Revolutionary, 28.

12 Ibid. Tentang Injil, Borg berpendapat bahwa "as documents written in the last third of the first century, they are the result of a developing tradition. During the decades between Jesus historical life and the writing of the gospels, the traditions about Jesus developed."

13 Ibid.

${ }^{14}$ Ibid, 25. Menurut Borg, "within this framework, the Bible and the gosples (like the sacred scriptures of other religions) are human responses to the sacred. They tell us not what God says, but what our spiritual ancestors said."

${ }^{15}$ Marcus J. Borg, "The Historical Study of Jesus and Christian Origins," in Jesus at 2000, ed. Marcus J. Borg (Boulder: Westview, 1997), 125.; Yudi 
kembangan ini juga menguatkan faktor subyektivitas penulisan Injil. Dengan mempertimbangkan kedua hal ini, aspek manusiawi Injil sebagai tulisan manusia dan aspek perkembangan Injil sebagai bagian dari tradisi lisan, ia melihat bahwa Injil jelas tidak cukup hanya dibaca dengan lensa historis-literal, karena "much of the language of the gospels is metaphorical,"16 dan Borg menawarkan sebuah metode pembacaan yang lebih kritis, yaitu pembacaan metaforis. ${ }^{17}$

Pembacaan metaforis tidak berfokus pada nilai historis teks, tetapi pada makna spiritual yang terkandung di balik teks tersebut. Menurut hemat Borg, "this way of seeing the gospels moves beyond a literalfactual reading and, very importantly, emphasizes their truth as metaphor." 18 Ia menilai bahwa hanya pembacaan yang demikianlah yang dapat membawa para pembaca ke dalam kekayaan berita Injil yang bertujuan mentransformasi hidup manusia. Hanya melalui pembacaan metaforislah makna dan intensi perbuatan serta pengajaran Yesus dapat dimengerti dalam tingkat ke-

Jatmiko, "Konsep Otoritas Alkitab Di Hadapan Fakta Kesalahan Tekstual: Sebuah Diskusi Teologis," Veritas : Jurnal Teologi dan Pelayanan 16, no. 1 (2017): 1-16, accessed October 2, 2021, http://repository.seabs.ac.id/handle/123456789/310.

${ }^{16}$ Borg, Jesus: Uncovering the Life, Teachings, and Relevance of A Religious Revolutionary, 51.

${ }^{17}$ P. J. W. Schutte, "Reading the Bible Again with Marcus Borg," HTS : Theological Studies 60, no. 1_2 (2004): 411-429, accessed October 2, 2021, https://journals.co.za/doi/abs/10.10520/EJC35803.

Schutte berargumen bahwa proposal yang Borg dalaman maksimal. Borg juga menegaskan bahwa metode pembacaan ini merupakan kombinasi dari memori historis dan naratif metaforis. ${ }^{19}$ Mengenai hal ini, ia menggarisbawahi demikian:

In particular, the emerging paradigm sees the gospels and the Bible very differently. Indeed, for the study of Jesus, this is the most central difference. Rather than seeing them as divine product and therefore as inerrant, and rather than interpreting them literally and factually, it sees them as human historical products that are to be read as a combination of historical memory and metaphorical narrative. ${ }^{20}$

Borg percaya bahwa "this approach integrates the insights of the historical-critical method with the realization that much of the language of the Bible is metaphorical, that is, more-than-literal, more-than-historical, in its meaning. ${ }^{21}$ Menurut hemat Borg, jika diterapkan dengan baik, konsep ini akan menolong pembaca untuk lebih mengerti intensi dari perkataan dan tindakan Yesus dalam Injil. ${ }^{22}$

tawarkan ini sangat relevan dan insightful bagi komunitas Kristen pascamodern.

${ }^{18}$ Borg, Jesus: Uncovering the Life, Teachings, and Relevance of A Religious Revolutionary, 51.

${ }^{19}$ Marcus J. Borg, The Heart of Christianity (New York: HarperSanFransisco, 2003), 45-46.

${ }^{20}$ Borg, Jesus: Uncovering the Life, Teachings, and Relevance of A Religious Revolutionary, 24-25. Ia menyebut pendekatan ini sebagai "historicalmetaphorical paradigm."

${ }^{21}$ Ibid.

${ }^{22}$ Borg, The Heart of Christianity, 46. 


\section{Konsep Kesadaran Spiritual Yesus}

Alasan kedua mengapa baptisan Yesus tidak boleh dimaknai dalam perspektif kristologis berkaitan erat dengan konsep kesadaran spiritual Yesus. Borg mengamati bahwa Yesus tidak hidup dalam sejarah yang vakum, melainkan pada sebuah konteks ketegangan antara dua dunia: dunia imperial Romawi dan dunia sosio-religius Yahudi. ${ }^{23}$ Di satu sisi, dunia imperial Romawi mendominasi dan menekan segala tatanan kehidupan Yahudi pada waktu Yesus hidup. ${ }^{24}$ Keadilan sosial dan belas kasihan bukanlah nilai yang dapat ditemukan dalam keseharian hidup masyarakat pada waktu itu. ${ }^{25}$ Di sisi lain, konteks teologi dan budaya Yahudi berakar pada Pribadi Allah Yahweh yang sangat menjunjung tinggi keadilan sosial dan belas kasihan. ${ }^{26}$ Dua dunia ini menciptakan ketegangan yang menuntut respons Yesus. Borg menyarikan pemikirannya demikian:

The collision between Roman imperial theology and domination and

\footnotetext{
${ }^{23}$ Borg, Jesus: Uncovering the Life, Teachings, and Relevance of A Religious Revolutionary, 108.

${ }^{24}$ Ibid.

25 Edi Purwanto, "Peran Ekonomi, Politik, Dan Sosial Dalam Kekerasan Atas Nama Agama," DUNAMIS: Jurnal Teologi dan Pendidikan Kristiani 4, no. 1 (October 25, 2019): 111-126, accessed October 2, 2021, https://sttintheos.ac.id/ejournal/index.php/dunamis/article/view/204.

${ }^{26}$ Borg, Jesus: Uncovering the Life, Teachings, and Relevance of A Religious Revolutionary, 108.

${ }^{27}$ Ibid.

${ }^{28}$ Ibid. Menurutnya, "the pre-Easter Jesus was not God, but God was the central reality of his life."; Marcus J. Borg and N. T. Wright, The Meaning of Jesus (New York: HarperCollins, 2007), 145-156.
}

the Jewish social world led to a variety of Jewish responses. . . This is the world that shaped Jesus - the world in which he grew up and the world that he addressed. And a further factor shaped him: his experience of God and his relationship with God. God was central in his life. ${ }^{27}$

Dalam pemikiran Borg, Yesus tidak lebih dari manusia pada umumnya. ${ }^{28}$ Namun, Ia adalah pribadi yang mampu melihat keterkaitan antara dua dunia ini dan menghubungkannya dengan konsep spiritualitas. ${ }^{29}$ Maksudnya ialah kedalaman relasi spiritualitas Yesus dengan Allah memungkinkanNya untuk menyelami rencana Allah dalam mewujudkan keadilan sosial dan belas kasihan di tengah ketegangan dua dunia tersebut, dan kedalaman spiritualitas ini dimulai melalui visi baptisan Yesus oleh Yohanes Pembaptis. ${ }^{30}$ Borg menilai bahwa "this is when Jesus became aware of being Spiritanointed, Spirit-filled. According to Mark, this is the beginning of the story of Jesus an experience of the Spirit of God." 31

\footnotetext{
29 Borg mengatakan bahwa "Jesus stands is this tradition of Jewish figures for whom God, the sacred, was an experiential reality" (Borg, Jesus: Uncovering the Life, Teachings, and Relevance of A Religious Revolutionary, 117.)

30 Barbara Immroth and W. Bernard Lukenbill, "Marcus Borg's Emerging Paradigm for Christianity: The Interplay of GLBT Readers, Religious Text, and Social Environment," Journal of Religious \& Theological Information 13, no. 3-4 (October 2, 2014): 88-110, accessed October 2, 2021, https://www.tandfonline.com/doi/abs/10. 1080/10477845.2014.963475.

${ }^{31}$ Borg, Jesus: Uncovering the Life, Teachings, and Relevance of A Religious Revolutionary, 121.
} 
Jauh dari pemaknaan keilahian identitas Yesus, Borg memaknai peristiwa baptisan-Nya sebatas pengalaman spiritual. ${ }^{32}$ Namun, ini bukanlah pengalaman spiritual biasa. Meminjam istilah Rudolf Otto, Borg melihat bahwa baptisan Yesus adalah "the mysterium tremendum et facinans - the tremendous mystery that fills us with awe and also attracts and allures us." ${ }^{33}$ Menurutnya, baptisan Yesus adalah sebuah pengalaman spiritual yang misterius, yang mendorong-Nya menjadi pribadi penyalur karya Allah dalam dunia yang merendahkan keadilan dan belas kasihan. ${ }^{34}$ Pengalaman spiritual ini membentuk Yesus menjadi pribadi yang spiritual. Spiritualitas Yesus mewujud dalam kehidupan pribadiNya (doa dan puasa), pengajaran-Nya (tentang dunia roh dan kerajaan Allah), dan interaksi-Nya dengan manusia dan dunia di sekeliling-Nya. ${ }^{35}$ Baginya, semua ini tidak mungkin terjadi jika Yesus tidak mengalami baptisan spiritual yang bersifat misterius itu. Singkatnya,

The synoptic gospels thus inaugurate their story of Jesus's public activity with stories of visions. Throughout the rest of their portrayal of Jesus, there are multiple

\footnotetext{
${ }^{32}$ Ibid, 41. Menurut Borg, baptisan Yesus adalah " $a$ private experience of Jesus."

${ }^{33}$ Ibid. 113.

${ }^{34}$ Ibid. 109.

${ }^{35}$ Ibid, 125-129. Borg menggunakan berbagai istilah untuk menunjukkan hal ini, seperti "Spirit and teaching," "Spirit and healing," "Spirit and presence," "Spirit and contemplative prayer," dan "Spirit and intimacy with God."
}

indicators that Jesus's message and activity were grounded in his experience of the Spirit of God. Stories about him and sayings and teachings attributed to him affirm that for Jesus, God was an experiential reality and that this was central and foundational to all that he became. ${ }^{36}$

Dengan demikian, Borg melihat bahwa baptisan Yesus bukan sekadar menjadi titik awal pengalaman spiritual-Nya dengan Allah, tetapi juga menjadi titik sentral yang menentukan arah, kualitas, dan wawasan dunia pelayanan-Nya.

Mengapa Borg hanya melihat baptisan Yesus sekadar pengalaman spiritual? Ini juga tidak lepas dari konsepnya tentang panenteisme. Borg menilai bahwa baptisan Yesus mengilustrasikan apa yang ia sebut sebagai "panentheism" dalam Alkitab. ${ }^{37}$ Panenteisme, dalam pemikiran Borg, ialah "God is here, all around us, even as God is also more than everything. It thus provides a framework for understanding what it means to speak of experiencing God." ${ }^{\text {"38 }} \mathrm{Ia}$ menilai bahwa konsep panenteisme adalah konsep yang paling mewakili doktrin Allah di Alkitab karena merangkum sisi transendensi dan imanensi Allah secara bersamaan. ${ }^{39}$ Dalam sudut pandang panenteisme

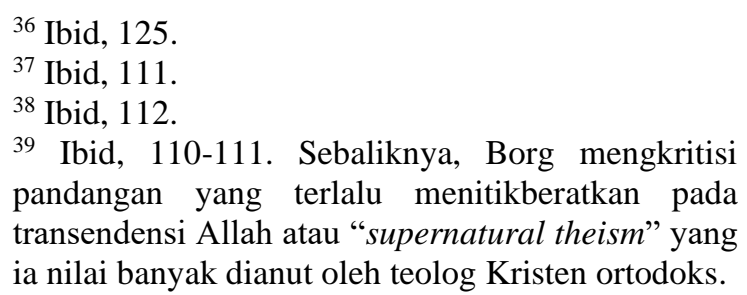
pandangan yang terlalu menitikberatkan pada transendensi Allah atau "supernatural theism" yang ia nilai banyak dianut oleh teolog Kristen ortodoks. 
inilah ia melihat bahwa pengalaman spiritual Yesus menjadikan Allah "nyata" dan "berada di dalam" hidup-Nya. Konsep panenteisme ini penting karena ini menjadi dasar bagi kemungkinan adanya pengalaman akan Allah. ${ }^{40}$ Bagi Borg, maksud Yesus dalam baptisan tidak ada kaitannya dengan pengungkapan identitas ilahi-Nya karena ia memang tidak ilahi. Tetapi, dalam perspektif panenteisme ini, baptisan Yesus menunjukkan bahwa pengalaman akan Allah dapat menjadikan hidup manusia biasa bersifat spiritual dan berdampak bagi transformasi masyarakat sekelilingnya. ${ }^{41}$ Menurut Borg, Yesus adalah bukti nyata hal tersebut. $^{42}$

\section{Konsep Yesus Prapaskah dan Pascapaskah}

Konsep pemisahan antara Yesus prapaskah dengan Yesus pascapaskah adalah hal yang amat kentara dalam teologi Borg dan menjadi alasan ketiga penolakannya terhadap kristologi baptisan Yesus. Di berbagai tulisannya, umumnya pada bagian

\footnotetext{
${ }^{40}$ Ibid, 112. Menurut Borg, "God can be experienced and that experiences of God are foundational to the Bible as a whole."

${ }^{41}$ Borg, Jesus: A New Vision, 196.

${ }^{42}$ Borg, Jesus: Uncovering the Life, Teachings, and Relevance of A Religious Revolutionary, 308.

43 Misalnya dalam Borg, Borg, The Heart of Christianity, 82-83. Borg, Jesus: Uncovering the Life, Teachings, and Relevance of A Religious Revolutionary, 44-45.; Borg, Jesus: A New Vision, 1-8.; Marcus J. Borg, "From Galilean Jew to the Face of God: The Pre-Easter and Post-Easter Jesus," in Jesus at 2000, ed. Marcus J. Borg (Boulder: Westview, 1997), 7-13.
}

awal, ia selalu mengingatkan pembaca untuk memiliki kesadaran akan kedua pemisahan ini. ${ }^{43}$ Yesus prapaskah adalah Yesus sebelum kematian-Nya; Yesus pascapaskah adalah Yesus setelah kematian-Nya. ${ }^{44}$ Yesus prapaskah adalah Yesus sejarah, sedangkan Yesus pascapaskah adalah apa yang selama ini disebut sebagai Kristus iman. Borg menyarikan bahwa "whereas the pre-Easter Jesus was finite and mortal, the post-Easter Jesus is spoken as a divine reality. . . As the Christian tradition develops, the post-Easter Jesus is spoken of as one with God and as having the qualities of God." 45 Borg berpendapat bahwa pemisahan ini penting sekali agar pembaca Injil dapat "bertemu" dengan Yesus yang sesungguhnya. Maksudnya ialah dengan Yesus yang belum mendapatkan pemaknaan doktrinal oleh komunitas Kristen mulamula.

Yesus yang sesungguhnya, menurut Borg, adalah Yesus prapaskah. ${ }^{46}$ Yesus dalam pengertian yang demikian adalah Yesus

\footnotetext{
${ }^{44}$ Borg, Jesus: Uncovering the Life, Teachings, and Relevance of A Religious Revolutionary, 44. Perhatikan bahwa Borg di sini tidak mengaitkan kata "Easter" dengan peristiwa kebangkitan karena dalam konsepsi Borg, kebangkitan adalah pemaknaan doktrinal, bukan peristiwa historis. Jadi, sekalipun Borg menggunakan kata "Easter," ia memaknainya bukan sebagai kebangkitan, melainkan sebagai kematian. Kebangkitan (Easter) hanya dimaknai secara metaforis.

45 Ibid, 45.

${ }^{46}$ Ibid, 47.
} 
yang "apa adanya" sebelum mendapatkan pemaknaan atau pun refleksi spiritual dari gereja mula-mula. Borg menilai bahwa "this Jesus, the pre-Easter Jesus, is a figure of the past, dead and gone, nowhere anymore." 47 Yang tinggal sekarang ialah "semangat" spiritualitas Yesus yang Ia tunjukkan semasa hidup-Nya. Menurutnya, semangat mewujudkan keadilan dan belas kasihan inilah yang seharusnya mewujudnyata dalam komunitas Kristen, alih-alih konstruksi doktrinal yang dipaksakan tentang keilahian Yesus. ${ }^{48}$

Mengaitkan konsep pemisahan ini dengan peristiwa baptisan Yesus, Borg menyarankan untuk pembaca berhati-hati dengan muatan doktrinal pascapaskah yang mengaitkan hal ini dengan identitas ilahi Yesus. ${ }^{49}$ Menurut Borg, konsep yang sarat dengan muatan kristologi harus ditolak karena merupakan hasil dari perkembangan refleksi teologis dan pemaknaan tambahan terhadap peristiwa baptisan. Mengenai hal ini, ia menegaskan:

About the historical factuality of Jesus' baptism by John and the

\footnotetext{
${ }^{47}$ Ibid, 44.; Zach Czaia, "What Marcus Borg's Video Camera Might Have Seen If He'd Been Filming in Jerusalem in the Days Following the Death of the Jewish Peasant Jesus," Christianity and Literature 63, no. 3 (2014): 372, accessed October 2, 2021, https://muse.jhu.edu/article/738908/summary.

48 Borg and Wright, The Meaning of Jesus, 229. Menyetujui Borg, Ioanes Rakhmat mengatakan bahwa "visi etikal Yesus yang semacam ini tentu akan mendorong setiap orang Kristen untuk memandang penting kehidupan di masa kini di dunia ini, sebagai kesempatan berharga satu-satunya untuk mengalami dan meneruskan pengalaman hidup
}

vision itself, there is little reason for doubt.... However, about the words spoken by the heavenly voice, "You are my Son, the Beloved; with you I am well pleased," there is reason for historical uncertainty, simply because the words so perfectly express a post-Easter perception of Jesus's identity. As such, this may well be the product of the followers of Jesus in the years after Easter. ${ }^{50}$

Visi Yesus tentang suara ilahi yang menjadi deklarasi keilahian-Nya layak untuk dicurigai. Borg menilai bahwa ini mengaburkan makna yang sesungguhnya dari peristiwa baptisan tersebut. Pertanyaannya sekarang ialah apa makna sesungguhnya dari peristiwa baptisan Yesus?

Borg menguraikan pentingnya untuk melihat konteks pengalaman spiritual Yahudi di mana Yesus hidup pada waktu itu untuk memahami maksud Yesus dalam peristiwa baptisan. ${ }^{51}$ Ia mempertajam maksudnya demikian:

But how we interpret "my Son" in this passage affects the historical judgment. If "Son" is given the theological meaning that it later came to have among Christians, then the phrase must be viewed as post-Easter or at least put into a

dalam pemerintahan kerahiman Allah." (Ioanes Rakhmat, "Kajian Yesus Sejarah Dan Sumbangannya Bagi Kehidupan Kristen Masa Kini," Jurnal Teologi Proklamasi 7, no. 4 (2006): 111.). Yang Rakhmat maksudkan dengan "visi etikal Yesus" ialah mewujudkan keadilan dan belas kasihan yang melampaui kepentingan dan kebenaran nilai doktrinal.

${ }^{49}$ Borg, Jesus: Uncovering the Life, Teachings, and Relevance of A Religious Revolutionary, 120.

${ }^{50}$ Ibid, 121.

${ }^{51}$ Ibid, 115. 
"suspense account." But if given the meaning that it has in stories of Jewish charismatics contemporary with Jesus, then it is historically possible to imagine this as part of the experience of Jesus. ${ }^{52}$

Pertanyaannya, kisah-kisah karismatis seperti apakah yang Borg maksudkan? Ia meneliti bahwa Kitab Suci Yahudi (PL) sarat dengan pengalaman-pengalaman spiritual para tokoh Alkitab, misalnya visi dan panggilan Yesaya dan Yeremia, penglihatan Daniel, serta visi Yehezkiel. ${ }^{53}$ Jika para tokoh tersebut dapat mengalami Allah sedemikian rupa secara spiritual, begitu juga halnya dengan Yesus.

Dengan demikian, Borg menyimpulkan bahwa konsep kristologi dalam baptisan adalah sesuatu yang harus ditolak karena bernuansa pascapaskah. Peristiwa baptisan menunjukkan kefanaan dan keberdosaan Yesus bahwa "Jesus went to be baptized by John because he thought of himself as a sinner in need of repentance." ${ }^{54}$ Borg memahami peristiwa baptisan Yesus sebagai sebuah pengalaman spiritual yang menjadi titik awal sekaligus titik sentral kehidupan dan pelayanan-Nya.

\section{Tanggapan Teologi Injili Terhadap}

\section{Konsep Marcus J. Borg}

Berbanding terbalik dengan apa yang Borg uraikan pada bagian sebelumnya

\footnotetext{
52 Ibid, 121.

${ }^{53}$ Ibid, 115-116.

${ }^{54}$ Ibid, 41.
}

mengenai makna baptisan Yesus, para teolog injili melihatnya sebagai bagian yang tidak lepas dari identitas keilahian-Nya. Pada bagian ini, dengan berpijak pada perspektif injili, penulis akan menanggapi dan mengkritisi tiga konsep Borg sebelumnya. Penulis kemudian akan menyajikan apa yang menjadi maksud Yesus dalam peristiwa baptisan menurut perspektif injili.

\section{Metafora Sebagai Bagian dari Genre Alkitab}

Usulan Borg mengenai bahasa Injil sebagai metafora dihasilkan dari dua prasuposisi dasar: Injil semata-mata produk manusia dan Injil adalah hasil dari budaya lisan yang berkembang. Penulis mendapati beberapa masalah dalam pemikirannya ini. Pertama, sebagai sebuah karya sastra, Injil jelas adalah tulisan manusia yang mengalami perkembangan dalam kurun masa penulisannya. ${ }^{55}$ Ini menegaskan natur manusiawi dari Injil. Namun, Injil juga memiliki natur ilahi sebagai "tulisan yang diilhamkan Allah" (2 Tim. 3:16). Lagipula, rasul Petrus mengingatkan bahwa, "Yang terutama harus kamu ketahui, ialah bahwa nubuat-nubuat dalam Kitab Suci tidak boleh ditafsirkan menurut kehendak sendiri, sebab tidak pernah nubuat dihasilkan oleh kehen-

55 David A. DeSilva, An Introduction to the New Testament: Context, Methods, and Ministry Formation (Downers Grove: InterVarsity, 2004), 151. 
dak manusia, tetapi oleh dorongan Roh Kudus orang-orang berbicara atas nama Allah" (2 Pet. 1:20-21). Darrell L. Bock mengingatkan bahwa seringkali yang men-jadi masalah dalam studi Yesus Sejarah adalah kekeliruan wawasan dunia seorang peneliti teologi terhadap natur Kitab Suci. ${ }^{56}$ Para peneliti Yesus Sejarah umumnya men-dekati Alkitab (khususnya Injil) dengan ka-camata kecurigaan dan penolakan terhadap aspek ilahi dari Alkitab. ${ }^{57}$ Inilah yang Borg lakukan.

Kedua, kegagalan melihat dwinatur Injil, dan juga keseluruhan Alkitab, membuat Borg menentang otoritas Alkitab. Sikap yang demikian berkontradiksi dengan tujuan transformatif yang hendak Borg capai, yaitu bahwa pengalaman akan Allah dapat menjadikan hidup manusia biasa bersifat spiritual dan berdampak bagi trans-

\footnotetext{
56 James K. Beilby and Paul R. Eddy, eds., "The Historical Jesus: Evangelical View," in The Historical Jesus: Five Views (London: SPCK, 2010), 249. Maksudnya, penyangkalan para teolog Yesus Sejarah terhadap otoritas Alkitab akan sertamerta berdampak negatif terhadap seluruh bangunan teologi mereka. Mengenai hal ini, Lukito telah memperingatkan bahwa "otoritas Alkitab akan menentukan seluruh perjalanan arah teologi dan kesaksian orang Kristen" (Lukito, “490 Tahun Reformasi : Apakah Sola Scriptura Masih Secara Konsisten Menjadi Pegangan Gereja-Gereja Reformed Masa Kini?" 167).

${ }^{57}$ Sean F. Everton, "What Are The Odds?: The Jesus Seminar's Quest for Objectivity," Journal for the Study of the Historical Jesus 13, no. 1 (October 29, 2015): 24-42, accessed October 2, 2021, https://brill.com/view/journals/jshj/13/1/articlep24_3.xml.; Bock, "The Historical Jesus: Evangelical View," 249.
}

formasi masyarakat sekelilingnya. Alur logikanya cukup jelas: perubahan transformatif tidak mungkin terjadi tanpa adanya otoritas normatif yang menyertainya. ${ }^{58} \mathrm{Un}$ tuk mencapai tujuan transformatifnya, Borg perlu mengakui otoritas normatif dari Injil.

Ketiga, hal lain yang agaknya luput dari pengamatan Borg ialah tentang natur dari metafora sebagai bagian dari genre Alkitab. Berkenaan dengan natur manusiawinya, para penulis Injil menulis dengan keunikan mereka masing-masing. ${ }^{59}$ Usulan Borg tentang pembacaan metaforis Injil menarik dan terkesan insightful namun tidak teliti. Injil ditulis dalam berbagai bentuk genre seperti narasi, perumpamaan, bahkan puisi. ${ }^{60}$ Mengatakan bahwa sebagian besar bahasa Injil adalah metafora ialah kesimpulan yang terburu-buru dan kurang mempertimbangkan keunikan natur manusiawi Injil. ${ }^{61}$ Ini ironis mengingat Borg sangat

\footnotetext{
${ }^{58}$ John M. Frame, The Doctrine of the Word of God (Phillipsburg: P\&R, 2010), 523.

59 Luke Timothy Johnson, "Learning the Human Jesus: Historical Criticism and Literary Criticism," in The Historical Jesus: Five Views, ed. James K. Beilby and Paul R. Eddy (London: SPCK, 2010), 157. Senada dengan Johnson, Gordon D. Fee dan Douglas Stuart mengingatkan bahwa "one of the most important aspect of the human side of the Bible is that . . . God chose to use almost every available kind of communication: narrative history, genealogies, chronicles, laws of all kinds, poetry of all kinds, proverbs, prophetic oracles, riddles, drama, biographical sketches, parables, letters, sermons, and apocalypses" (Gordon D. Fee and Douglas Stuart, How to Read the Bible for All Its Worth (Grand Rapids: Zondervan, 2003), 22.).

${ }^{60}$ Fee and Stuart, How to Read the Bible for All Its Worth, 22.

${ }^{61}$ Ibid.
} 
mengagumi pendekatan teologi modern yang menitikberatkan pada natur manusiawi Injil. Yang benar ialah metafora hanyalah salah satu (bukanlah satu-satunya) cara untuk membaca Injil. Lagipula, metafora biasanya digunakan untuk membaca genre yang bersifat kiasan seperti perumpamaan dan puisi, sedangkan untuk narasi (seperti narasi baptisan Yesus) harus dibaca secara literal. ${ }^{62}$ Hermeneutika yang "pukul rata" akan menghasilkan kesimpulan yang keliru. Sebaliknya, hermeneutika yang sesuai dengan genre penulisan Injil akan membawa peneliti teologi pada kesimpulan yang proporsional. Agaknya, Borg perlu mempertimbangkan hal ini.

\section{Konsep Kesadaran Spiritual Yesus}

Pengamatan Borg tentang dua dunia dalam konteks kehidupan Yesus adalah pengamatan historis-kultural yang baik. Studi latar belakang sejarah dan budaya dalam penulisan Injil menunjukkan adanya ketegangan antara konteks Greeco-Roman dan komunitas Yahudi pada waktu itu. ${ }^{63}$ Namun beberapa hal perlu dikritisi berkaitan de-

62 F. David Farnell, "Three Searches for the 'Historical Jesus' But No Biblical Christ (Part 2): Evangelical Participation in the Search for The "Historical Jesus"," The Master's Seminary Journal 24, no. 1 (2013): 25-67.

${ }^{63}$ DeSilva menyoroti bahwa "Jews, especially those in the Diaspora, were faced with many challenges. They lived as a minority group in the midst of and daily proximity to a dominant, Gentile culture - one that frequently made the Jew who remain aloof from the dominant culture feel inferior or unwelcome," lihat DeSilva, An Introduction to the New ngan pemikiran Borg ini. Pertama, jika dikaitkan kedua dunia ini dengan kesadaran spiritual Yesus, yang Borg fasilitasi melalui ide panenteisme adalah sebuah lompatan kesimpulan yang agak dipaksakan. Ini disebabkan karena Borg berusaha membaca narasi baptisan Yesus dengan peristiwa spiritual yang dialami oleh tokoh-tokoh Alkitab lainnya (misalnya, Yesaya, Yeremia, dan Daniel). ${ }^{64}$ Pembacaan seperti itu bisa saja dilakukan tetapi yang menjadi masalahnya ialah apakah pembacaan yang demikian yang dimaksudkan oleh Injil Markus dalam peristiwa baptisan $?^{65}$ Jelas tidak! James R. Edwards menyarikan hal ini dengan indah bahwa "in the sublime declaration to Jesus at the baptism we encounter Fatherly love and filial obedience, kingship and suffering service. Each is a facet of what it means to be the Son of God. To no prophet had words been spoken such as the words to Jesus at the baptism." Peristiwa spiritual dan deklarasi ilahi yang terjadi pada baptisan Yesus tidak pernah dialami oleh tokoh-tokoh Alkitab lainnya.

Testament: Context, Methods, and Ministry Formation, 100.

${ }^{64}$ Borg, Jesus: Uncovering the Life, Teachings, and Relevance of A Religious Revolutionary, 115-116.

${ }^{65}$ Kata "bisa" yang penulis tekankan di atas merujuk pada kemungkinan adanya kekeliruan penafsiran, bukan pada adanya alternatif bagi kebenaran penafsiran.

${ }^{66}$ The Gospel According to Mark, 38. Penekanan oleh penulis. Kontraskan kalimat cetak tebal yang penulis tekankan dengan konsep kesadaran spiritual Yesus yang Borg asumsikan karena merujuk kepada para nabi di PL. 
Memaknai baptisan dari perspektif pengalaman spiritual tokoh Alkitab lainnya, seperti yang diusulkan Borg, tidak sesuai dengan kebenaran firman Tuhan.

Kedua, konsep panenteisme yang Borg katakan sebagai konsep Alkitab adalah menyesatkan. Kekristenan yang sehat berpijak pada Teisme Tritunggal ${ }^{67}$ yang menunjukkan perbedaan yang jelas antara Allah Pencipta dan dunia ciptaan, sekaligus menyatakan keterlibatan (bukan keidentikan $)^{68}$ Allah dalam dunia ciptaan. Ini amat berbeda dengan apa yang Borg katakan sebagai panenteisme. Menyimpulkan panenteisme sebagai doktrin Allah dalam Alkitab jelas keliru.

Ketiga, narasi baptisan Yesus dalam Injil Markus (dan juga dalam perikop paralelnya $)^{69}$ tidak mengindikasikan adanya saran untuk menafsirkan peristiwa ini sebagai sebuah kesadaran spiritual Yesus. Narasi ini menegaskan keilahian Yesus. Markus, sejak awal sekali di permulaan Injilnya, sudah memperkenalkan Yesus sebagai “Anak Allah” (Mrk.1:1). Ini menunjukkan bahwa Yesus yang Markus rujuk adalah "God's equal."70 Baptisan Yesus bukanlah

${ }^{67}$ R. C. Sproul, Essential Truths of the Christian Faith (Carol Stream: Tyndale, 1992), 35-36.

68 Sebagaimana yang diindikasikan oleh panenteisme, lihat C. Stephen Evans, Pocket Dictionary of Apologetics \& Philosophy of Religion (Downers Grove: InterVarsity, 2002), 88.

${ }^{69}$ Matius 3:13-17; Lukas 3:21-22; Yohanes 1:32-34 dengan sendirinya ini juga membantah konsep sebuah pengalaman spiritual yang membukakan kesadaran Yesus akan relasi spiritual-Nya dengan Allah. Sebaliknya, baptisan menegaskan identitas ilahi-Nya sebagai Mesias, Anak Allah. R. T. France menggarisbawahi hal ini dengan tepat ketika mengatakan:

Jesus . . . enjoys a special relationship to God, and God here endorses both his person and his mission. . . Clearly for Mark Jesus does not have to wait until the resurrection to become God's son: he is so already, and there is no hint that even at his baptism this is a new factor. What is new here is the launching into the public exercise of the role for which he, as Son of God, is thus prepared. ${ }^{71}$

Yesus tidak mengalami kesadaran ilahi atau kesadaran spiritual yang bertahap dalam peristiwa baptisan. Ia adalah Mesias, Anak Allah sejak pada mulanya. Baptisan adalah sebuah endorsement sekaligus announcement dari Allah Bapa tentang natur dan misi Yesus sebagai Mesias. Dengan demikian jelaslah sudah bahwa apa yang Borg asumsikan sebagai kesadaran spiritual Yesus dalam kerangka teologi panenteisme adalah hal yang jauh dari kebenaran firman Tuhan.

adoptionism, lih. Edwards, The Gospel According to Mark, 38.

70 Sigurd Grindheim, Christology in the Synoptic Gospels (London: T \& T Clark, 2012), 60.

${ }^{71}$ R. T. France, The Gospel of Mark (Grand Rapids: Eerdmans, 2002), 82-83. 


\section{Konsep Yesus Prapaskah dan Pascapaskah}

Konsep pemisahan antara Yesus prapaskah dan Yesus pascapaskah mendapat sambutan hangat dari para teolog non-injili, ${ }^{72}$ namun konsep ini bermasalah dalam beberapa hal. Pertama, konsep ini jelas berkontradiksi dengan keilahian Yesus yang ditegaskan oleh Allah Bapa dalam peristiwa baptisan, sebagaimana diuraikan pada poin sebelumnya. Membaca peristiwa baptisan dengan "kacamata" prapaskah adalah mengindikasikan adanya perkembangan perubahan natur keilahian Yesus. Ini tidak sesuai dengan penelitian terhadap deklarasi Allah Bapa dan juga studi kata tentang “Anak Allah” dalam Injil Markus. Senada dengan hal ini, William L. Lane menegaskan bahwa "Jesus did not become the Son of God, at baptism ...; he is the Son of God, the one qualified to bestow the Holy Spirit." $" 73$

Kedua, pemisahan ini juga bertolakbelakang dengan apa yang firman Tuhan katakan tentang kristologi yang sehat bahwa, "Yesus Kristus tetap sama, baik kemarin maupun hari ini dan sampai selamalamanya" (Ibr. 13:8). ${ }^{74}$ Ia sejak awal bersama-sama dengan Allah, adalah Allah

\footnotetext{
${ }^{72}$ Misalnya, Schutte, "Reading the Bible Again with Marcus Borg," 417-419 dan Rakhmat, "Kajian Yesus Sejarah Dan Sumbangannya Bagi Kehidupan Kristen Masa Kini."

73 William L. Lane, The Gospel of Mark (Grand Rapids: Eerdmans, 1974), 58.
}

(Yoh. 1:1-2) dan disebut sebagai Pencipta segala yang ada (Yoh. 1:3). Ia melakukan apa yang Allah lakukan, misalnya membangkitkan orang mati (Mrk. 5:35-42), mengusir setan (Mrk. 5:1-20), dan berkuasa atas maut (Mrk. 16:1-8; Mat. 28:1-10; Luk. 24:1-12; Yoh. 20:1-10). Alkitab juga mengajarkan bahwa Yesus adalah Alfa dan Omega, Yang Awal dan Akhir (Why. 1:8; 21:6; 22:13) dan akan menghakimi seluruh manusia (Why. 5:7-8). Alkitab tidak membedakan antara Yesus prapaskah dengan Yesus pascapaskah. Ia adalah Allah, sebelum dan setelah kebangkitan-Nya.

Berdasarkan berbagai argumentasi yang penulis tunjukkan pada bagian ini, ketiga poin yang diajukan Borg berkenaan dengan baptisan Yesus - konsep metafora bahasa Injil, konsep kesadaran spiritual Yesus, dan konsep pemisahan antara Yesus prapaskah dan pascapaskah - tidak sesuai dengan pengajaran teologi yang sehat dan mengaburkan maksud Yesus yang sesungguhnya dalam peristiwa baptisan.

\section{Maksud Yesus dalam Peristiwa Baptisan Menurut Perspektif Injili}

Penulis sependapat dengan Edwards yang mengamati adanya keterkaitan antara

\footnotetext{
74 F. David Farnell, "Three Searches for the 'Historical Jesus' But No Biblical Christ: The Rise of the Searches (Part 1)," The Master's Seminary Journal 23, no. 1 (2012): 7-42.; Dennison, "How Is Jesus the Son of God? Luke's Baptism Narrative and Christology."; I Howard Marshall, Commentary on Luke (Grand Rapids: Eerdmans, 1978), 150-157.
} 
baptisan Yesus, sebagai Israel Sejati dalam $\mathrm{PB}$, dengan kegagalan Israel sebagai umat Allah dalam PL. ${ }^{75}$ Narasi PL mengisahkan bagaimana Israel sebagai umat pilihan Allah berkali-kali gagal untuk hidup seturut dengan ketetapan-ketetapan Allah. Kitab Keluaran dan Bilangan secara khusus mengisahkan bagaimana Israel berkali-kali membang-kitkan murka Tuhan melalui sungut-sungut me-reka (misalnya, Kel. 16:135 tentang makanan; Kel. 17:1-7 tentang minuman; Bil. 11:1-3 tentang nasib buruk; dan Bil. 14:1-38 tentang ketidakpercayaan kepada Tuhan). Israel yang tegar tengkuk gagal menjadi berkat bagi bangsa-bangsa lain. $^{76}$ Dalam peristiwa baptisan, Yesus tampil sebagai Israel sejati untuk menggenapi rencana Allah yang gagal digenapi oleh Israel. ${ }^{77}$ Ini dibuktikan oleh beberapa

75 James R. Edwards, "The Baptism of Jesus According to the Gospel of Mark," Journal of the Evangelical Theological Society 34, no. 1 (1991): 43-44.

${ }^{76}$ Edwards, The Gospel According to Mark, 38.; Bandingkan dengan Kejadian 12:1-3.

${ }^{77}$ Edwards, "The Baptism of Jesus According to the Gospel of Mark."; Leon Morris, The Gospel According to Matthew (Grand Rapids: Eerdmans, 1992), 64-65.

${ }^{78}$ Langit yang terkoyak dan Roh Kudus turun dalam rupa burung merpati merupakan alusi dari PL, lih. Edwards, "The Baptism of Jesus According to the Gospel of Mark."; Robert L. Webb, “Jesus' Baptism by John: Its Historicity and Significance," in Key Events in the Life of the Historical Jesus: A Collaborative Exploration of Context and Coherence, ed. Darrel L. Bock and Robert L. Webb (Grand Rapids: Eerdmans, 2010), 112.; Larry W. Hurtado, Mark (Peabody: Hendrickson, 1989), 1921.; David E. Garland, Mark (Grand Rapids: Zondervan, 1996), 48-49.

79 Ronald J. Kernaghan, IVP New Testament Commentary Series: Mark (Downers Grove: hal: pertama, alusi yang digunakan oleh penulis Injil dalam peristiwa baptisan merujuk kepada permulaan (inauguration) zaman baru; sebuah zaman di mana Kerajaan Allah memerintah. ${ }^{78}$ Itulah sebabnya misi Yesus setelah baptisan berfokus pada pemberitaan tentang kerajaan Allah; kedua, ungkapan “Anak-Ku, yang Kukasihi” tidak pernah ditujukan kepada siapa pun kecuali kepada Israel (dalam PL) dan Yesus (dalam PB). ${ }^{79}$ Ini menegaskan bukan hanya keter-kaitan Yesus dengan Israel, tapi juga kesempurnaan-Nya untuk menggantikan ketidaksempurnaan Israel ${ }^{80}$ ketiga, peristiwa baptisan diikuti dengan peristiwa Yesus dicobai di padang gurun. ${ }^{81}$ Rangkaian dua peristiwa ini (baptisan dan pencobaan) merupakan alusi kepada kegagalan Israel untuk taat kepada Allah di padang gurun, sekali-

InterVarsity, 2007), 37. Dalam studi intertestamental, suara dari Sorga ini seringkali dikaitkan dengan "bat-qôl" atau yang disebut sebagai " a distant echo or 'daughter of a voice.". Fenomena ini merujuk kepada ucapan langsung dari Allah Yahweh kepada Israel, umat-Nya, lih. Edwards, "The Baptism of Jesus According to the Gospel of Mark."

${ }^{80}$ Edwards menyarikan ini dengan tepat bahwa "only Israel (Exod. 4:23) and the king as Israel's leader (Ps. 2:7) - had been called God's Son before. But where Israel failed, Jesus takes its place," lihat Edwards, "The Baptism of Jesus According to the Gospel of Mark."

${ }^{81}$ Injil Sinoptik sepakat mengenai urutan baptisanpencobaan ini. Hanya Injil Yohanes yang tidak mencantumkan perikop pencobaan di padang gurun. Kemungkinan besar ini terkait dengan tujuan teologis Injil Yohanes yang berbeda dengan Injil Sinoptik, lih. D. A. Carson, The Gospel According to John (Grand Rapids: Eerdmans, 1991), 151-152.; J. Ramsey Michaels, The Gospel of John (Grand Rapids: Eerdmans, 2010), 113-114. 
gus penegasan bahwa Yesuslah Israel sejati yang taat kepada Allah. ${ }^{82}$

Dengan demikian, melalui peristiwa baptisan, Yesus bermaksud menegaskan datangnya zaman baru di mana Allah memerintah dan perkenanan Allah turun atas umat yang tergabung dalam karya penebusan Kristus. Dengan kata lain, dapat disimpulkan bahwa baptisan Yesus tidak dapat dilepaskan dari makna kristologis yang melekat pada diri-Nya sendiri.

\section{KESIMPULAN}

Makna baptisan Yesus yang Borg ajukan, sekadar sebagai sebuah pengalaman spiritual yang misterius, jauh dari maksud Yesus yang sesungguhnya dalam peristiwa baptisan tersebut. Peristiwa baptisan menegaskan identitas ilahi Yesus, sebagai Mesias, Anak Allah, sekaligus menunjukkan peran yang diemban-Nya sebagai Israel sejati untuk menuntaskan ketaatan yang sempurna terhadap Allah demi penebusan dosa umat pilihan-Nya. Ketidaksesuaian pemikiran Borg tentang baptisan Yesus dengan pemikiran Injili tidak lain oleh karena ia semata-mata melihat Alkitab dari kacamata sosio-antropologis, sebagai produk tanggapan iman pada zamannya, dan bukan sebagai suatu wahyu dari Allah.

\section{DAFTAR PUSTAKA}

Bock, Darrell L. "The Historical Jesus: Evangelical View." In The Historical Jesus: Five Views, edited by James K. Beilby and Paul R. Eddy. London: SPCK, 2010.

Borg, Marcus J. "From Galilean Jew to the Face of God: The Pre-Easter and PostEaster Jesus." In Jesus at 2000, edited by Marcus J. Borg. Boulder: Westview, 1997.

- Jesus: A New Vision. San Francisco: Harper\&Row, 1987.

-. Jesus: Uncovering the Life, Teachings, and Relevance of $A$ Religious Revolutionary. New York: HarperSanFransisco, 2006.

- Jesus in Contemporary Scholarship. Valley Forge: Trinity, 1994.

Meeting Jesus Again for the First Time: The Historical Jesus \& the Heart of Contemporary Faith. New York: HarperCollins, 1994.

- The God We Never Knew: Beyond Dogmatic Religion to A More Authentic Contemporary Faith. New York: HarperCollins, 1997.

- The Heart of Christianity. New York: HarperSanFransisco, 2003.

—. "The Historical Study of Jesus and Christian Origins." In Jesus at 2000, edited by Marcus J. Borg. Boulder: Westview, 1997.

- "What Did Jesus Really Say?" Bible Review 5, no. 5 (1989): 18-19.

Borg, Marcus J., and N. T. Wright. The Meaning of Jesus. New York: HarperCollins, 2007.

Carson, D. A. The Gospel According to John. Grand Rapids: Eerdmans, 1991.

\footnotetext{
${ }^{82}$ Edwards, The Gospel According to Mark, 39.
} 
Czaia, Zach. "What Marcus Borg's Video Camera Might Have Seen If He'd Been Filming in Jerusalem in the Days Following the Death of the Jewish Peasant Jesus." Christianity and Literature 63, no. 3 (2014): 372. Accessed October 2, 2021. https:// muse.jhu.edu/article/738908/summary

Dennison, Charles G. "How Is Jesus the Son of God? Luke's Baptism Narrative and Christology." Calvin Theological Journal 17, no. 1 (1982): 6-25.

DeSilva, David A. An Introduction to the New Testament: Context, Methods, and Ministry Formation. Downers Grove: InterVarsity, 2004.

Edwards, James R. "The Baptism of Jesus According to the Gospel of Mark." Journal of the Evangelical Theological Society 34, no. 1 (1991): 43-44.

- The Gospel According to Mark. Grand Rapids: Eerdmans, 2002.

Evans, C. Stephen. Pocket Dictionary of Apologetics \& Philosophy of Religion. Downers Grove: InterVarsity, 2002.

Everton, Sean F. "What Are The Odds?: The Jesus Seminar's Quest for Objectivity." Journal for the Study of the Historical Jesus 13, no. 1 (October 29, 2015): 24-42. Accessed October 2, 2021. https://brill.com/view/journals/ jshj/13/1/article-p24_3.xml.

Farnell, F. David. "Three Searches for the 'Historical Jesus' But No Biblical Christ: The Rise of the Searches (Part 1)." The Master's Seminary Journal 23, no. 1 (2012): 7-42.

"Three Searches for the "Historical Jesus' But No Biblical Christ (Part 2): Evangelical Participation in the Search for The "Historical Jesus"." The Master's Seminary Journal 24, no. 1 (2013): 25-67.
Fee, Gordon D., and Douglas Stuart. How to Read the Bible for All Its Worth. Grand Rapids: Zondervan, 2003.

Frame, John M. The Doctrine of the Word of God. Phillipsburg: P\&R, 2010.

France, R. T. The Gospel of Mark. Grand Rapids: Eerdmans, 2002.

Frazer, Nicole Christine. "Marcus Borg: A New Vision of Jesus." Global Journal of Classic Theology 3, no. 2013 (10AD): 1-18.

Garland, David E. Mark. Grand Rapids: Zondervan, 1996.

Grindheim, Sigurd. Christology in the Synoptic Gospels. London: $\mathrm{T} \& \mathrm{~T}$ Clark, 2012.

Hurtado, Larry W. Mark. Peabody: Hendrickson, 1989.

Immroth, Barbara, and W. Bernard Lukenbill. "Marcus Borg's Emerging Paradigm for Christianity: The Interplay of GLBT Readers, Religious Text, and Social Environment." Journal of Religious \& Theological Information 13, no. 3-4 (October 2, 2014): 88-110. Accessed October 2, 2021. https://www.tandfonline.com/ doi/abs/10.1080/10477845.2014.9634 75 .

Jatmiko, Yudi. “Konsep Otoritas Alkitab Di Hadapan Fakta Kesalahan Tekstual: Sebuah Diskusi Teologis." Veritas : Jurnal Teologi dan Pelayanan 16, no. 1 (2017): 1-16. Accessed October 2, 2021. http://repository.seabs.ac.id/ handle/123456789/310.

Johnson, Luke Timothy. "Learning the Human Jesus: Historical Criticism and Literary Criticism." In The Historical Jesus: Five Views, edited by James K. Beilby and Paul R. Eddy. London: SPCK, 2010. 
Kernaghan, Ronald J. IVP New Testament Commentary Series: Mark. Downers Grove: InterVarsity, 2007.

Lane, William L. The Gospel of Mark. Grand Rapids: Eerdmans, 1974.

Lukito, Daniel Lucas. "490 Tahun Reformasi: Apakah Sola Scriptura Masih Secara Konsisten Menjadi Pegangan Gereja-Gereja Reformed Masa Kini?" Veritas: Jurnal Teologi dan Pelayanan 8, no. 2 (2007): 151168. Accessed October 2, 2021. http://repository.seabs.ac.id/handle/12 $3456789 / 158$.

Marshall, I Howard. Commentary on Luke. Grand Rapids: Eerdmans, 1978.

Michaels, J. Ramsey. The Gospel of John. Grand Rapids: Eerdmans, 2010.

Morris, Leon. The Gospel According to Matthew. Grand Rapids: Eerdmans, 1992.

Perard, R. V. "Evangelicalism." In Evangelical Dictionary of Theology, edited by Walter A. Elwell. Grand Rapids: Baker, 1982.

Purwanto, Edi. "Peran Ekonomi, Politik, Dan Sosial Dalam Kekerasan Atas Nama Agama." DUNAMIS: Jurnal Teologi dan Pendidikan Kristiani 4, no. 1 (October 25, 2019): 111-126.
Accessed October 2, 2021. https:// sttintheos.ac.id/e-journal/ index.php/dunamis/article/view/204.

Rakhmat, Ioanes. "Kajian Yesus Sejarah Dan Sumbangannya Bagi Kehidupan Kristen Masa Kini.” Jurnal Teologi Proklamasi 7, no. 4 (2006): 111.

Schutte, P. J. W. "Reading the Bible Again with Marcus Borg." HTS : Theological Studies 60, no. 1_2 (2004): 411-429. Accessed October 2, 2021. https:// journals.co.za/doi/abs/10.10520/EJC3 5803.

Sproul, R. C. Essential Truths of the Christian Faith. Carol Stream: Tyndale, 1992.

Webb, Robert L. "Jesus' Baptism: Its Historicity and Implications." Bulletin for Biblical Research 10, no. 2 (2000): 261-309. Accessed October 2, 2021. https://www.jstor.org/stable/2642222 1.

. "Jesus' Baptism by John: Its Historicity and Significance." In Key Events in the Life of the Historical Jesus: A Collaborative Exploration of Context and Coherence, edited by Darrel L. Bock and Robert L. Webb. Grand Rapids: Eerdmans, 2010. 